\title{
Wade in the Water: Awash in the Sense of Adoption
}

\author{
Denise Blake, Mandy Morgan \& Leigh Coombes \\ deniseblake@xtra.co.nz,C.A.Morgan@massey.ac.nz,L.Coombes@massey.ac.nz \\ School of Psychology, Massey University, Palmerston North, New Zealand
}

\begin{abstract}
A discursive approach to knowledge contends that language is the constitutive force of experience and lived reality. Meaning is created through language use within relationships, while discourses function as the statements that produce knowledge, power and truth claims. We cannot step outside of the discourses through which our knowledge of experience is produced, though their complexity always allows us to resist particular identities that are discursively available to us. Based on interviews with 12 adoptees constituted within the 'closed' adoption period between 1955 and 1985 , this narrative analysis represents the way in which the adoptive body matters to participants' experiences of adoption and their resistances to the discourses that produce knowledge of adoption: Embodiment needed to be incorporated into this discursive work. Knowing, accessing and beingin-the-world are achieved through our senses in everyday life. We engage and shape cultural norms that enable and constrain corporeality. The adoptive experience is lived and felt through bodies that struggle to articulate their corporeality through discourse. Without discourses fit for purpose, speaking embodiment in and through adoption is precarious and adoptees attempt to articulate subjectivities beyond those allowed. This paper discusses the strategies used to materialise body matters in researching adoption.
\end{abstract}

Keywords: Adoption, Adoptees, Body, Identity, Birth family, Adoptive family, Reunion.

\section{Introduction}

Institutions use language at the political, cultural and small group level to inform social practices, such as adoption. These institutional discourses become the rules and values that govern and allow subjects to make sense of the world and to act from those positions (Danaher, Schiratio, \& Webb, 2000; Parker, 2002; Ramazanoglu, 1993). Discourses do not represent some preexisting 'reality' that awaits discovery, but are the "practices that systematically form the objects of which they speak" (Foucault, 1972, p. 49). Possibilities outside of that which it speaks are limited by the available social discourses (Gutting, 2005; Hare-Mustin \& Marecek, 1988; Weedon, 1999). Stepping outside is precarious for it risks not making sense. For the adopted subject, language to represent the adoption experience is limited and bound by every-day, non-adopted knowledge of family, identity and 'self'.

A space outside of taken-for-granted family norms is rarely accessible and the stories and experiences of adoptees struggle to be told otherwise. The "paradox of untellability" where language is constitutive and "falls short of its task - it disintegrates under the strain" (Wajnryb, 2001, p. 36), was clear to the research participants in the study that the first author has conducted. For Jan, being an adoptee, displaced from her birth family was "a knowing; it is actually more than just having a house and land, it's knowing, yeah, that I haven't actually got words for really" (971) ${ }^{1}$. Similarly, for Maxine adopted experiences are "always hard to explain because it's kind of like a lot of, it is kind of pre-verbal you know and it's accessing that kind of stuff" (104). The adoptive body matters to how experiences of adoption are lived and any resistances to the discourses that regulate adoption.

When I (first author) ponder what being adopted means my body whispers sounds, feelings and instinct, but it is unable to enunciate from that particular place. When I attempt to theorise how my body matters, my body speaks but in a feeling sense and I cannot name those feelings. Yet here the body hurts. Just like the research participants, in producing a text about adoption and adopted experiences I am constrained in and through my positioning within the taken-for-granted language of kinship, family, body and 'self'. Similarly, while attempting to theorise the adopted body I rely on the language and theories of others, and

\footnotetext{
Numbers in brackets represent line numbers of the participants' transcribed interviews.
} 


\section{WADE IN THE WATER}

finding words to enunciate a particular space for an adoptee is fraught when language for those experiences has not been specifically produced. As an adoptee, I too fight against the structure of language that disallows the place for me, the adopted subject. It is as if that place is just beyond my reach. And like Butler (1993) when I try to feel the "materiality of the body" I always find myself in "other domains" (p. ix). It is because of this, the materialisation of the adopted body necessarily needs to be understood within this work. The adopted body is a lived/felt body that enunciates within a particular discursive space.

By tracing the historical, social and moral practices of adoption, it became clear that the adopted body is produced the same as nonadopted bodies and the bodies that are produced in mainstream psychological research are constituted as either pathological or informative to genetic heritability, effectively silencing adopted bodies.

\section{Silencing Adopted Bodies}

\section{The Legislated Body}

In 1955, the Adoption Act came into effect in Aotearoa/New Zealand and legislated adoption as a social practice that completely severed all ties with the birth family. To enable this, Section 16(2)a of the Adoption Act (1955) established that it would be "as if the child had been born to that parent in lawful wedlock", thereby producing the child as a legal fiction. Fiction in law, a contradiction to fact, is deemed acceptable with practical implications, such as righting the wrong of illegitimacy and hiding the immorality of the birth mothers' indiscretions' (Griffith, 1991; Ludbrook, 2008). The 'complete break' climate meant adoptees were not granted any contact with 'bad' birth parents or their families, legally or socially. Over 80,000 adoptees were constituted within this legislative and social Act (Griffith, 1991).

When Vaughn described his illegitimate position, he said "I wasn't good enough ... I think you'll be judged ... that you are nobody" $(272,425,427)$. To be born illegitimate, was to be born with no rights to a name, education or family and it was believed that illegitimacy posed a significant risk to public morality (Carp, 2009; Gillard-Glass \& England, 2002; Griffith, 1998). To be "no-body" produces adoptees as less than, (not of this social world) and here they suffer an inherent shame, the embodied condition of their/our birth.
The implementation of the Adoption Act (1955) engaged social practices that served to keep signs of illegitimacy and adoption concealed. This included practices of secrecy to hide the adoptee's birth shame, to protect the adoptive family from being positioned as different to traditional families (and/ or to hide infertility) and to enable a life trajectory for the birth mother without retribution for her shameful behaviour. Great effort was made to protect the birth secret and its bodily implications, including adoptive mothers creating pregnant bodies by using pillows to imitate pregnancy (Else, 1991), matching observable genetic traits between adoptive parents and the child (hair, eye and skin colour and/or intelligence), and sending the birth mother away to discrete homes to have the child (Else, 1991; Griffith, 1998).

Further, the consequences of the adoption event were not discussed, and little or no information was provided to the adopted child about their birth origins. Margaret said, "I knew I came from somewhere that I wasn't allowed to know anything about. I remember having fights when I was really little, about why won't you tell me and I actually don't think they knew very much, well they certainly weren't forthcoming and [my adoptive mother] used to get very upset saying - "why do you want to know? I can't tell you anything" (104). It was assumed that a good, loving environment would override any genetic predisposition and more than compensated for any birth family loss (Griffith, 1991). Acting as if would produce secure attachment with adoptive parents and enable 'stable' identities for the adopted child within the adoptive family (Watkins, 2006).

However, as some adoptees grew to maturity they began to contest the denial of any rights to a birth history, and after years of lobbying against the 1955 Act as a human rights violation, the Adult Adoption Information Act came into force in 1985. The power of that legislation was to overturn the particular strategy that had suppressed adoptees' rights to know details of their birth. Adoptees could now access their original birth certificates, which usually provided only a birth mother's name. Reunion became possible (Else, 1997; Griffith, 1982). However, the embodied silence and lived effects of being enabled and constrained in political and social discourses that shunned and disallowed a birth history made reunions problematic. And again for adoptees, this lived experience is difficult to story, as Barry testifies: 
Unless you've been separate from it and then reconnected to it you aren't going to know that ... I mean like if you are not adopted then you've always had that connection ... if you haven't been adopted and haven't been reconnected then you don't know you've lost it ... like you have to have an awareness of having it then losing it, to know that it wasn't there $(563,566,570,572)$.

Barry signifies how living as an adoptee is not understood by others that have always had blood-as-kinship relationships and that this is a 'felt' embodied experience, an awareness of the presence of the absence.

\section{The Psychological Body}

Particular versions of adopted bodies are found in psychological research ${ }^{2}$. While tracing the social, moral and political history of adoption, it is apparent that where the adopted body has been discussed it is a deviant, pathological body that is only valued for its physiological character. The way in which this body is represented has mattered because psychology as a knowledge producing institution searches for a knowledge that does particular things to particular subjects in specific ways.

The adopted body is represented through the study and application of behaviour genetics. Here, traditional psychology assumes it can gain insight into human behaviour and provide universal language and criteria for mental disorders (American Psychiatric Association, 2000). Adoptees are a valued population in genetic research because it becomes possible to separate genes from contextual and environmental factors and researchers can examine early experiences and the influence of heritability of particular diseases or disorders. Birth parents pass on their genes, but another set of parents raise the child, so it is assumed that research can ascertain if variables are biologically heritable, or produced through parental patterns, or the environment (Palacios \& Sanchez-Sandoval, 2005).

Within psychology, genetic research involves investigating familial patterns, examining firstdegree biological relatives for a particular disorder and comparing those results to that of the general population. Within the DSM-IV (American Psychiatric Association, 2000), adoption studies highlight a three to fourfold increase in risk for

$2 \quad$ For example see the work of Grotevant, Dunbar, Kohler, and Lash Esau (2000), Juffer and van IJzendoorn (2007) and Triseliotis (1973).
Alcohol Dependence when children were adopted out of birth families and had adoptive parents without Alcohol Dependence. Adoption studies also help demonstrate a genetic component to Somatization Disorder and Bipolar I Disorder, with first-degree biological relatives of people with Bipolar I Disorder shown to have elevated rates of Bipolar I Disorder (4\%-24\%), Bipolar II Disorder (1\%-5\%), and Major Depressive Disorder (4\%-24\%). Wegar (2000) recognises that a biological or genetic lens on adoption focuses on the problematic aspects of adoptees' 'inferior' genetic make-up, which resonates with the 'fears' of inheriting 'bad blood' that are evident in the arguments for legal adoption. This emphasis on causality as being 'in the blood', negates the complexity of social relations in which an adoptee is embedded.

The occurrence of Genetic Sexual Attraction as an effect of the adopted body has received research and social attention. Genetic Sexual Attraction was a term first coined by Barbara Gonyo, a birth mother who experienced an overwhelming 'sexual' desire for her birth son when they were reunited. Genetic Sexual Attraction refers to a particular relationship that occurs between two biologically related adults, after having been separated at birth or in early infancy. Although they are biologically connected, these adults have no kinship affinity because they were not raised together and legally they are no longer related since the child is reconstituted as if born to another family (Greenberg, 1997). Genetic Sexual Attraction and particular forms of adopted pairings are positioned as problematic because they are unusual and equated with incest, a taboo in most cultures. With the moral abhorrence of incestuous relationships, societies have strategies for dealing with those who break the incest taboo, including social denunciation and legal sanction: imprisonment. During the closed adoption period, adoption legislation attempted to protect against such incidences by providing access to information about biological identities for adoptees in special circumstances that included checks to prevent marrying a blood relative (Griffith, 1997; Rockel \& Ryburn, 1988). However, this did not always work and for the reuniting bodies that experience overwhelming feelings, emotions and sensation without discourses fit for purpose, it follows that sexuality becomes a form of sense making for these events. That something happens in the adopted body is not contested here; adoption is lived 


\section{WADE IN THE WATER}

and felt at a cellular level as Maxine describes, "there's nothing intellectual about adoption and the intellectual stuff is the adult stuff, the rest is cellular and umm, you know, it's so profound" (584).

The first author also describes her experiences of a cellular embodiment, "I learnt about the cellar level when my birth mother reached out and touched my arm for the first time and I felt a surge of electricity race through my nerves. It was an overwhelmingly unforgettable experience and the significance of it still puzzles me today".

Other than representing the adopted body through and in genetic and pathological discourse, where the adopted body is reduced to genetic heritability of disorder or pathologised through Genetic Sexual Attraction, how the adopted body matters is ignored in research. Therefore, to enable the lived/felt experience of the adopted body to be written/spoken, theories of the body need to be taken up. The following section discusses the strategies the first author used to materialise body matters in adoption research.

\section{Theorising Adopted Bodies}

Freeman $(2002,2010)$ proposes a way to understand shared histories and memories effecting bodies after a poignant and heartfelt visit to Germany, which involved sights and sounds becoming "a kind of living, breathing presence... [a] monument to memory" (p. 197). He questioned the possibility of an energy field or a non-material trace of past traumatic events that linger and give rise to a sense of, and an experience of a self. Here the past becomes inscribed in the present; it remains alive and active though not consciously 'known'. This experience is named the 'narrative unconsciousness' or that which has been lived but un-thought and affects bodies. Here the cultural dimension of autobiographical narratives and cultural texts are stitched into the fabric of memory. Barry understands the importance of history and cultural texts. He wants others also to privilege this knowledge:

I just, that's my dream, do you know what I mean? That we understand that family and our connection to it, to our genetic family, to our biological family is huge. It is who we are, it's not just who we are right now, but it's who, where we've come from, it's, it is our (tears), it is our ancestors (1745).

A 'narrative unconsciousness' is more than the private, inner dimensions understood by psychoanalyticunderstandingsofunconsciousness; sources beyond the boundary of a subject become woven into memory. Freeman $(2002,2010)$ proposes that the 'narrative unconsciousness' is the mostly unrecognised and therefore uncognised part of our histories that is inherited through our status as historical beings. We become aware of this 'narrative unconsciousness' at the moment our historical and cultural situatedness comes into view. Brendon experienced this on the first reunion meeting with his birth mother:

[It] was amazing aye and instantly there's a connection - that whole unspoken thing - there's just whole catching eyes and just, our ancestors are there, you know with us, on our shoulders (tears) (562).

While talking about this experience, Brendon began to cry, his tears represent the grief and connection that was embodied. Embodiment, according to MacLachlan (2004), encompasses an "abstract idea with a physical entity" (p. 2), for instance, the shaming action or social discourse becomes embodied when notions of shame are represented in the body (sinking feeling in the stomach, head lowered). Embodiment, rather than the body as an empirical object, is the vital condition of psychological and social life. As a medium for displaying our social-psychological conditions, our embodiment talks to the collective and individual positions we take towards one other and that shape the world in which we meet (Radley, 1996). For example, Griffith (1991) states that adoptees know they have been rejected by their birth mother and embody the fear that it may happen again. To anticipate further rejection is not only experienced as "anxiety", but because the "fear of rejection" is always present, it also represents difference. Cooley said "I do have, you know, abandonment issues as an adult ... just get into a bit of a panic state of feeling really quite, sort of, you know, a bit anxious" $(142,723)$. Embodiment enables adopted bodies to be the conduit to display what matters and how, and is a key to the social world. The physical body is bounded to individual corporeal events involving social judgments and constraints of bodily actions (Radley, 1996). It is recognised that the body feels pain, gets sick, has desires and is dependent upon the material world; however, we are more than a physical experience through our individuated bodies (Radley, 1996). And in this sense, we engage and shape cultural norms to enable or prohibit our bodily functions. 


\section{Blake, Morgan \& CoOMBes}

Embodiment represents the way in which the body cannot be separated from the mind, contrary to the Cartesian mind/body split (MacLachlan, 2004). In the seventeenth century, Descartes heralded the emergence of a mind/body dualism, where mind is considered non-physical. As an epistemological assumption, this view has come to be widely accepted with the distinction between the mental and physical continuing today. As shown through traditional adoption research, the body is treated as an object in which to measure, treat and modify disorders of mind. At this site, it is also argued that empirical knowledge can only be obtained by removing human senses because they are positioned as unreliable.

Contesting this mind/body split, Merleau-Ponty (1962) argues for a body-subject because knowing, accessing and being-in-the-world are achieved through our senses in everyday life. Often takenfor-granted, perception in lived experience is how we exist; it is devoid of conscious thought, but not of subjective being. Before rational thinking, before our thoughts facilitate concepts and language, our body is always already engaged. In this theory, Maxine's pre-verbal body that was difficult for her to access becomes legitimate and valued. The body-subject is the foundation of thinking. We see, we hear, we feel - we use our perception.

Merleau-Ponty (1962), a phenomenologist, professed that we must rediscover the world though perception, a way of being we are prone to forget because rational thinking is valued. Discarding dualistic thought, Merleau-Ponty argues that the mind and body are interwoven; one cannot exist without the other. Embodied we exist in the physical, denying this is to deny our existence at all. According to Noland (2009), Merleau-Ponty is interested in how the body is implicated in what the mind thinks it knows.

Although assigning a place for the body, Merleau-Ponty is still situated within the discursive turn. Language as part of our human survival produces and reproduces the depth or quality of our experience. The body is foundational and through the actions of embodying language where it is spoken through sounds in space and time, the body is able to live and speak to others (Munro \& Belova, 2009). Language cannot be conceived of as an addition to the body, with speech the conduit of thought because often we do not know our own thoughts until spoken.
Our embodied existence is in relationship to the world, our experience of the world is influenced and influences our experience of being-in-theworld (MacLachlan, 2004). We do not experience our own or others bodies as objects. However, in everyday living, we are not aware of minds and bodies separately, just of other human beings. Knowledge of ourselves and others are experienced as a unified whole (Matthews, 2002). And how we relate to our own and other bodies matters to our being in the world.

In this sense, when we understand behaviour from the 'inside' it can enable phenomena, for example illness, disability, disease or dysfunction to be understood as more than mechanical malfunctioning of an object. Some experiences have emotional meaning to give them a quality and a relationship to other qualities that enables connections among experiences that otherwise have nothing in common. We only know others through their bodies; the way they move, talk, gesture and so forth (Crossley, 1996). Phenomenology is also not a-historical, it values lived experience as historically and culturally mediated (Solomon, 2006). Merleau-Ponty represented the social and the biological as inseparable processes.

An important facet of Merleau-Ponty's arguments is the movement away from the idea of a transcendental ego (an identity that our minds create), and the meaning attached to consciousness. It involves a style of thinking that sheds what we know as existence, or what we commonly think of as existence. In doing this we do not withdraw the self (as a transcendental ego) from the world, but open ourselves up to a more explicit understanding of the ways in which we are bound to, and situated in the world. By loosening our conscious threads, a phenomenological analysis cannot become a complete reduction as we cannot separate ourselves from our embodied world (Gutting, 2001).

Merleau-Ponty's theorising of a body, according to Gutting (2001), includes intentionality or the union between the world and consciousness. This unity is the fundamental beginning of phenomenology. Merleau-Ponty interpreted Husserl's notion of intentionality to mean more than knowing and experiencing the world through acts of consciousness that are directed towards some object, it is a fundamental priority which is intrinsic to us (Gutting, 2001). Here, the body as perceiving and experiential is intimately entwined 


\section{WADE IN THE WATER}

and engaged with the world. Merleau-Ponty makes a shift in his understanding of intentionality to encompass notions of motility (Solomon, 2006) where the body inhabits time and space, and intentions are not secondary to the object. Movement matters.

In relation to adoption, Merleau-Ponty's case of the 'phantom limb', which he uses to argue the need for a being-in-the-world paradigm, provides a metaphor for an adoptees' embodied sense of their missing birth mother. In the case of the phantom limb, after an amputation, it is possible to experience the missing limb as if it is still present. Physiological and psychological theories cannot explain this phenomenon in isolation. However together, they enable a more comprehensive understanding, and remove the need to select between describing the present nerve transmissions or the not present remembered limb. MerleauPonty (1962) asserts that the absent limb is still in relationship to parts of the world that 'speak' to the limb and it has an ambivalent presence. The subject retains a practical knowing of action that was present before the limb was lost; the habitual body learns to do things in the world with continuous repetition, such as turning a doorknob or drinking from a glass. This impersonal response remains even when the personal experience of actually doing these things is no longer available.

The adopted subject experiences the presence of the absent birth mother in much the same sense, and here she is the phantom mother. Although removed, the birth mother remains present through bodies that question the why and how of relinquishment. For Maxine, they had "already bonded - they'd long ago bonded - it was already you know there, part of it, it already had its genetic history, it had nine months you know it was already a being" (901, 909). The connection of the body matters and for Mary, while her "birth mother was sent away...that feeling definitely goes, has to go ... the feelings of the mother definitely go across to the child" $(542,544)$.

Our being-in-the-world is ambiguous. In the phantom limb example, the limb is a part of the past that remains quasi-present, it is more than a memory - it is a virtual experience. This experience can often remain on the periphery but at times, and in particular situations, it becomes central (Gutting, 2001). Likewise, the absent presence of birth mothers for adoptees may move from the periphery to a more central aspect of our experience.

Merleau-Ponty represents the body as 'lived' (Crossley, 1996). Here, the adopted body can be valued as constituted and constituting adoptive experiences. Being-in-the world for adoptees occurs at the site of the body, and matters to how it is lived.

Foucault provides another way to materialise the adopted body. Here, knowledge as a form of power and a model of surveillance enables the regulation and disciplining of bodies. Foucault's notion of 'bio-power' represents the way in which the human body is enmeshed in social practices which lead to processes of acculturation, knowledge and truth (Burkitt, 1999; Danaher, et al., 2000).

Power enacted on bodies is not located within a subject, institution or structure; power is ubiquitous (Foucault, 1982). Moreover, power, according to Foucault, exists only when it is enacted. To this effect knowledge becomes a practical form of power as it performs disciplinary actions on the body; it regulates thinking, controls behaviour and orders emotions (Clegg, 1997). Disciplinary power is efficient because subjects embody knowledge and rules to govern their own behaviour. When the social dictums are internalised, subjects then become their own overseers. The state does not need to exert its power through dictatorship and force, instead practices of rationality and technologies of control implement political rule (Danaher, et al., 2000; Gutting, 2001; Rose, 1999; Sarup, 1993). Power in this way involves minimal cost to governments (Sarup, 1993).

Burkitt's (1999) reading of Foucault suggests that biological life is entangled with history and emotion and narrative sense making. Each interacts and affects one another. The body is at the root of this connection between biology and history, and as the body moves with time so has the human capacity to think and know.

Foucault represents the body as inscribed (Crossley, 1996). Adoptees, for example, embody secrecy and silence as a moral code for behaviour and as dictated by the Adoption Act (1955). Many adoptees do not overtly resist that code or perform outside of the desired socially sanctioned understanding of family as different or 'other'. As bodies are inscribed by particular rules it means they are always, already there. They are 


\section{Blake, Morgan \& COOMBES}

acted, often without thought. Brendon describes how feelings inhabit his body and when they overwhelm, he acts his anger:

When these feelings are too big to process it's so easy, it's so much easier to flick into anger... and acting out angrily, being angry ... 'cause it's easy man, it's nice to let the, to vent the steam you know, and it's so easy, I just so want to like 'go' society then, man - to let happen what happened. It's fucken not okay (laugh) man (440, 444, 446).

\section{Body Matters}

This paper discussed body matters for adoptees. These matters include the strategies of silence that occurred because of the social, moral and political discourses that regulated the adopted subject as if born to and thereby the same as nonadopted subjects. Concealing a birth history meant adoptees were not allowed to discuss, resist or know about the born to relationship. They were positioned as the same as and equal to the nonadopted body. And while the adopted body is spoken to within traditional knowledge producing institutions, the privileging of the rational, unified subject meant adoptees were only understood in genetic or pathological speak. Instead, this work suggests that the ideas of Freeman, MerleauPonty and Foucault offer strategies through which to understand the complexity of the multi-vocal adopted body and how that might matter to the lived experience of being-in-the world as if born to. That the adopted body is unlike the nonadopted body matters, and in this way the adopted body necessitates theoretical accessibility.

Dr Denise Blake is a Senior Tutor at Massey University, Wellington. She completed her Doctoral study in 2013. By taking up a poststructuralist position alongside a phenomenological approach, her research represents the way in which the adoptive body matters to adoptees' experiences of adoption, while exploring the discourses that enable and constrains them.

\section{References}

Adoption Act. (1955). Adoption Act 1955 s93 [Electronic Version]. Retrieved from http://www. legislation.govt.nz/act/public/1955/0093/latest/ DLM292661.html

American Psychiatric Association. (2000). Diagnostic and statistical manual of mental disorders fourth edition (4-TR ed.). Washington, DC: American Psychiatric Association.
Burkitt, I. (1999). Bodies of thought: Embodiment, identity and modernity. London, England: Sage.

Butler, J. (1993). Bodies that matter: On the discursive limits of "sex". New York, NY: Routledge.

Carp, E. W. (2009). How tight was the seal? A reappraisal of adoption records in the United States, England and New Zealand, 1851 - 1955. In G. M. Wrobel \& E. Neil (Eds.), International advances in adoption research for practice (pp. 18-39). Oxford, England: Wiley-Blackwell.

Clegg, S. (1997). Power relations and the constitution of the resistant subject. In J. M. Jermier, D. Knights \& W. R. Nord (Eds.), Resistance and power in organizations (pp. 274-325). London, England: Routledge.

Crossley, N. (1996). Body-subject/body-power: Agency, inscription and control in Foucault and Merleau-Ponty. Body \& Society, 2(2), 99-116. doi: $10.1177 / 1357034 X 96002002006$

Danaher, G., Schiratio, T., \& Webb, J. (2000). Understanding Foucault. Crows Nest, Australia: Allen \& Unwin.

Else, A. (1991). A question of adoption. Wellington, New Zealand: Bridget Williams Books.

Else, A. (1997). The uses of history in adoption education and healing. In New Zealand Adoption Education and Healing Trust (Ed.), International Conference on Adoption and Healing (pp. 50-56). Wellington, New Zealand: New Zealand Adoption Education and Healing Trust.

Foucault, M. (1982). Afterword: The subject and power. In H. L. Dreyfus \& P. Rabinow (Eds.), Michel Foucault: Beyond structuralism and hermeneutics (pp. 208-226). Chicago, IL: University of Chicago Press.

Freeman, M. (2002). Charting the narrative unconscious: Cultural memory and the challenge of autobiography. Narrative Inquiry, 12(1), 193-211. doi: 10.1075/ ni.12.1.27fre

Freeman, M. (2010). Hindsight: The promise and peril of looking backwards. Oxford, England: Oxford University Press.

Gillard-Glass, S., \& England, J. (2002). Adoption New Zealand: A never-ending story. Auckland, New Zealand: Harper Collins.

Greenberg, M. (1997). Genetic sexual attraction. In New Zealand Adoption Education and Healing Trust (Ed.), International Conference on Adoption and Healing (pp. 94-100). Wellington, New Zealand.

Griffith, K. (1982). Adoption court records. Adoption action 1955 Section 23. Construction-cases-practice. Wellington, New Zealand: Keith Griffith. 


\section{WADE IN THE WATER}

Griffith, K. (1991). The right to know who you are: Reform of adoption law with honesty, openness and integrity. Toronto, Canada: Katherine W. Kimbell.

Griffith, K. (1997). The legal and social history of adoption in New Zealand. In New Zealand Adoption Education and Healing Trust (Ed.), International Conference on Adoption and Healing (pp. 45-49). Wellington, New Zealand: New Zealand Adoption Education and Healing Trust.

Griffith, K. (1998). New Zealand adoption: history and practice, social and legal, 1840-1996. Wellington, New Zealand: Keith Griffith.

Grotevant, H. D., Dunbar, N., Kohler, J. K., \& Lash Esau, A. M. (2000). Adoptive identity: How contex within and beyond the family shape developmental pathways. Family Relations, 49(4), 379-387. doi: 10.1111/j.1741-3729.2000.00379.x

Gutting, G. (2001). French philosophy in the twentieth century. Cambridge, England: Cambridge University Press.

Gutting, G. (2005). Foucault: A very short introduction. Oxford, England: Oxford University Press.

Hare-Mustin, R. T., \& Marecek, J. (1988). The meaning of difference: Gender theory, postmodernism, and psychology. American Psychologist, 43(6), 455-464. doi: 10.1037/0003-066X.43.6.455

Juffer, F., \& van IJzendoorn, M. H. (2007). Adoptees do not lack self-esteem: A meta-analysis of studies on self-esteem of transracial, international, and domestic adoptees. Psychological Bulletin, 133(6), 1067-1083. doi: 10.1037/0033-2909.133.6.1067

Ludbrook, R. (2008). Adoption law revision required. Retrieved from http://www.acya.org.nz/?t=53

MacLachlan, M. (2004). Embodiment: Clinical, critical and cultural perspectives on health and illness. New York, NY: Open University Press.

Matthews, E. (2002). The philosophy of Merleau-Ponty. Chesham, England: Acumen.

Merleau-Ponty, M. (1962). Phenomenology of perception (C. Smith, Trans.). London, England: Routledge \& Kegan Paul.

Munro, R., \& Belova, O. (2009). The body in time: Knowing bodies and the 'interruption' of narrative. The Sociological Review, 56(2), 85-99. doi: 10.1111/j.1467-954X.2009.00817.x

Noland, C. (2009). Agency and embodiment. Cambridge, England: Harvard University Press.

Palacios, J., \& Sanchez-Sandoval, Y. (2005). Beyond adopted/nonadopted comparisons. In D. Brodzinsky, M. \& J. Palacios (Eds.), Psychological issues in adoption: Research and practice (pp. 117-116). London, England: Praeger.
Parker, I. (2002). Critical discursive psychology. New York, NY: Palgrave MacMillan.

Radley, A. (1996). Displays and fragments: Embodiment and the configuration of social worlds. Theory \& Psychology, 6(4), 559-576. doi: 10.1177/0959354396064002

Ramazanoglu, C. (1993). Introduction. In C. Ramazanoglu (Ed.), Up against Foucault. Explorations of some tensions between Foucault and feminism (pp. 18-25). London, England: Routledge.

Rockel, J., \& Ryburn, M. (1988). Adoption today: Change and choice in New Zealand. Auckland, New Zealand: Heinemann Reed.

Rose, N. (1999). Governing the soul: The shaping of the private self. London, England: Free Association Books.

Sarup, M. (1993). An introductory guide to poststructuralism and post-modernism (2nd ed.). Hertfordshire, England: Harvester Wheatsheaf.

Solomon, R. C. (2006). Emotions in phenomenology and existentialism. In H. L. Dreyfus \& M. A. Wrathall (Eds.), A companion to phenomenology and existentialism (pp. 291-309). Oxford, England: Blackwell.

Triseliotis, J. (1973). In search of origins: The experiences of adopted people. London, England: Routledge \& Kegan Paul.

Wajnryb, R. (2001). The silence: How tragedy shapes talk. Crows Nest, NSW: Allen \& Unwin.

Watkins, M. (2006). Adoption and identity: Nomadic possibilities for reconceiving the self. In K. Wegar (Ed.), Adoptive families in a diverse society (pp. 259274). New Brunswick, NJ: Rutgers University Press.

Weedon, C. (1999). The production and subversion of gender: Postmodern approaches. Oxford, England: Wiley-Blackwell.

Wegar, K. (2000). Adoption, family ideology, and social stigma: Bias in community attitudes, adoption research, and practice. Family Relations, 49(4), 363370. doi: 10.1111/j.1741-3729.2000.00363.x 